Article

\title{
Models of Intersectoral Cooperation in Municipal Health Promotion and Prevention: Findings from a Scoping Review
}

\author{
Eike Quilling ${ }^{1, *, \dagger}$, Stefanie Kruse ${ }^{2, *, \dagger}$, Maja Kuchler ${ }^{1}$, Janna Leimann ${ }^{1}$ and Ulla Walter ${ }^{3}$ \\ 1 Department of Applied Health Sciences, University of Applied Sciences, 44801 Bochum, Germany; \\ maja.kuchler@hs-gesundheit.de (M.K.); janna.leimann@hs-gesundheit.de (J.L.) \\ 2 Department of Social Work, University of Applied Sciences RheinMain, 65197 Wiesbaden, Germany \\ 3 Social Medicine and Health System Research, Institute for Epidemiology, Hannover Medical School, \\ 30625 Hannover, Germany; Walter.Ulla@mh-hannover.de \\ * Correspondence: eike.quilling@hs-gesundheit.de (E.Q.); stefanie.kruse@hs-rm.de (S.K.) \\ + Shared first authorship.
}

Received: 15 July 2020; Accepted: 11 August 2020; Published: 13 August 2020

\begin{abstract}
Intersectoral cooperation is regarded as a promising strategy in setting-oriented prevention and health promotion for interdepartmental, joint efforts towards improved health equity. This paper deals with models of intersectoral cooperation in municipal health promotion. It frames the methodology and the central results of a literature and database search (on behalf of the Federal Centre for Health Education, BZgA) and presents the partial results regarding the models of intersectoral cooperation. Of 48 publications analyzed for the review, nine publications each present different models of intersectoral cooperation. The models describe typical processes in the context of the joint work as detailed step sequences and formulate general recommendations as success factors of intersectoral cooperation. With reference to the findings of the review, it can be concluded that models for intersectoral cooperation have not yet been systematized and consequently have not been researched for transferability into specific fields of practice.
\end{abstract}

Keywords: intersectoral cooperation; urban health; health promotion

\section{Background}

Providing health care to as many citizens as possible in post-industrial and ageing societies is associated with enormous challenges. The health situation of citizens is still significantly influenced by milieu-specific factors such as education, housing, access to leisure and recreation areas, etc. [1,2]. On the one hand, people with a low socio-economic status are particularly affected by health inequalities and disadvantage [3,4]. Low income or poverty leads to cumulative health risks, which manifest themselves among other things in unequal access to healthy living environments [5,6]. In addition to this factor of socio-economic status, which highlights the parallel between social and health inequalities, other groups of people are considered vulnerable. Vulnerability can be determined on the one hand by questions of age: adolescents and older people in particular are particularly dependent on good access to health and healthy living environments $[7,8]$. Further vulnerability criteria are defined along specific lifelong trajectories, including experience of migration [9], long-term unemployment [10,11], or living with chronic diseases or one or more disabilities [12].

For around three decades, the focus has been increasingly shifting to integrated concepts for health care and health promotion as possible approaches to the goal of improved health [13]. The foundation for this is the enormous complexity of a segregatively organized health system in Germany on the one hand, and the established insight that health is the result of the interaction of diverse, multifaceted 
factors on the other hand. These factors are composed of individual, social, living-environment, social situation and socio-political starting conditions, and environmental factors, as presented, for example, in the model of determinants of health by Dahlgren and Whitehead (2006) [14]. Thus, prevention efforts and the promotion of health-promoting behavior go far beyond the domain of influence of the health care system and require the involvement of numerous policy areas and associated departments. The European Health Report 2015 identifies supporting frameworks for the strategic development of health promotion policies, including demand-driven and citizen-oriented health systems, a society-wide approach, the creation of enabling and supportive environments, and the development of resilient communities [15]. In the course of this, the municipality as an umbrella setting has a special significance and responsibility for the health promotion of its citizens [16]. Especially in urban areas, municipal health promotion stands, among other approaches, for the creation of environmentally sound, healthy social spaces $[17,18]$.

In line with the Health in All Policies strategy, health promotion today therefore is to be more clearly oriented towards the targeted interaction of different professions, disciplines, and sectors at national level and in federal states, municipalities, and neighborhoods in the form of intersectoral cooperation. Networking and cooperation across different sectors is seen as a key strategy, as the key to improving equity in health lies not in the health sector as a whole, but in the joint activities of different strategic partners [19]. Intersectoral networking is already well advanced in some health-related fields. In Germany, for example, numerous projects have been initiated with a cooperation network for health equity that include network structures for improved health as intersectoral forms of cooperation (Cooperation Network for Health Equity: Project-Directory) [20]. The Cooperation Network for Health Equity aims to create conditions for a healthy life for people in difficult social situations and with special burdens. As an association of 60 institutions and organizations, the cooperation network pursues the goals of networking, transparency, and quality and supports the exchange of information as an interface between practice, science, and politics. This national alliance finds its international counterpart in the European network Closing the Gap-Strategies to Tackle Health Inequalities in Europe, in which 22 national partners from the EU member states are involved and in the framework of which national strategies to reduce socially induced inequalities in health are documented and further developed [21]. Carried out on the basis of assured quality, coalitions can lead to the increased use of science-based interventions and thus increase the probability that these will have a positive impact on health [22,23]. However, given the complexity of the community as a living environment and its interdependent effects on the well-being and health of the people living there, there is no gold standard for measuring the evidence of intersectoral cooperation as a contribution to a complex multi-level strategy for health promotion in the community. Attempts to transfer the criteria of evidence-based medicine to municipal strategies for health promotion and prevention are reaching the limits of research methodology [24-26]. As actors from different disciplines and sectors already cooperate in many different ways in the practice of setting-based health promotion and prevention, there is still little knowledge available about the used models of intersectoral cooperation, their effectiveness, and the conditions and prerequisites necessary for this. There is a gap between the growing importance of intersectoral cooperation and the scientifically proven state of knowledge and recommendations for its practical implementation as a quality-assured procedure. This was the initial point for a literature-based review with the main focus on "Models and evidence of intersectoral cooperation in setting-based health promotion and prevention" (on behalf of the Federal Centre for Health Education, BZgA). The report on the results of this review shows that only very few studies attempt to systematically measure the evidence for intersectoral cooperation for health promotion [19]. This paper only presents the results of theoretical models and practical approaches to intersectoral cooperation in health promotion.

\section{Methodology}

Following Chircop et al. (2015) [27], intersectoral cooperation was defined as a formalized, exchange-based and goal-oriented relationship between different interest groups, which can be 
described through horizontal or vertical hierarchical relations. Based on this initial definition, 128 documents (relevant textbooks and material in German language) have been screened for contexts and definitions of the term "intersectoral cooperation" or alternative terms in order to develop a search strategy for the study. The results then were evaluated qualitatively and in part quantitatively as well. The high breadth and linguistic variance in the presentation of intersectoral cooperation stood out. In order to develop suitable search strings for the scoping review, numerous synonymous search terms for intersectoral cooperation were tested, among others by means of thesauri, agreed with the client and finally defined. This was the final English-language search string used in the Pubmed/Medline and Web of Science databases: (((health*[Title] OR promot ${ }^{*}$ [Title] OR prevent*[Title])) AND (intersector ${ }^{*}$ [Title] OR inter-sector*[Title] OR multisector*[Title] OR multi-sector*[Title] OR cross-sector*[Title] OR trans-sector*[Title] OR trans-organizati*[Title] OR interorganizati*[Title] OR trans-agen*[Title] OR inter-agen*[Title] OR multi-stake*[Title] OR interinstitution*[Title] OR inter-institution*[Title] OR multi-institution*[Title] OR cross-institution*[Title] OR trans-institution*[Title])) AND (cooperat*[Title] OR allian*[Title] OR coal ${ }^{*}[$ Title] OR partner*[Title] OR network*[Title] OR collaborat*[Title] OR relation*[Title] OR consort*[Title] OR align*[Title]).

A German-language pendant was established based on the preliminary work on linguistic specifics for the following search terms in the database LIVIVO: (Gesundheit* OR förder* OR prävent*) AND TI $=$ (intersektor* OR inter-sektor* OR multisektor* OR multi-sektor* OR transsektor* OR trans-sektor* OR trans-organisati* OR transorganisati * OR interorganisati* OR inter-organisati* OR multi-organisati* OR multiorganisati* OR übergreifend* OR interinstitution* OR inter-institution* OR multi-institution* OR cross-institution* OR trans-institution*) AND TI $=\left(\right.$ kooperat $^{*}$ OR allian* OR koal* OR partner* OR netz ${ }^{*}$ OR kollaborat* OR konsort* OR zusammen* OR bund* OR bünd* OR kette*).

On the basis of these defined inclusion and exclusion criteria in Table 1, 186 hits were exported to a literature management program in the research process according to a database-related backward- and forward strategy and after elimination of duplicates, and viewed by at least two reviewers. Fifty-seven publications were included in the full-text analysis for the review, to investigate the models and approaches to intersectoral cooperation. Figure 1 shows the result of the research and steps of inclusion based on the PRISMA scheme:

Table 1. Inclusion and exclusion criteria for the Scoping Review.

\begin{tabular}{|c|}
\hline Inclusion and Exclusion Criteria for the Scoping Review: \\
\hline $\begin{array}{l}\text { Only German and English language publications were included; publications in other languages were } \\
\text { excluded. }\end{array}$ \\
\hline Only publications published between 2010 and 2018 were included. \\
\hline Reviews, study results, grey literature, and reports were included in the full text analysis. \\
\hline $\begin{array}{l}\text { Abstracts, letters, comments and editorials, and contributions to the announcement of studies that do not yet } \\
\text { show results were excluded. }\end{array}$ \\
\hline $\begin{array}{l}\text { Only publications that specifically refer to intersectoral cooperation in prevention and health promotion were } \\
\text { included in the full text analysis. Publications that deal with intersectoral cooperation in the context of patient } \\
\text { care or the rehabilitative and nursing care system were systematically excluded. }\end{array}$ \\
\hline $\begin{array}{l}\text { Included were publications that refer to industrial nations with comparable care structures; excluded were } \\
\text { publications that refer to regions and/or populations that do not allow a transfer to German conditions. }\end{array}$ \\
\hline $\begin{array}{l}\text { Both narrative and systematic reviews were included as well as qualitative and quantitative studies and } \\
\text { reports on approaches and strategies of intersectoral cooperation, their evaluation and effectiveness, success } \\
\text { factors, and theoretical approaches and models. }\end{array}$ \\
\hline $\begin{array}{l}\text { The search strings were designed in such a way that only publications containing the search terms in the title } \\
\text { are considered. }\end{array}$ \\
\hline $\begin{array}{l}\text { For the sub-question on approaches and theoretical models examined here, only those texts describing } \\
\text { theoretical models and approaches were included in the analysis. }\end{array}$ \\
\hline
\end{tabular}




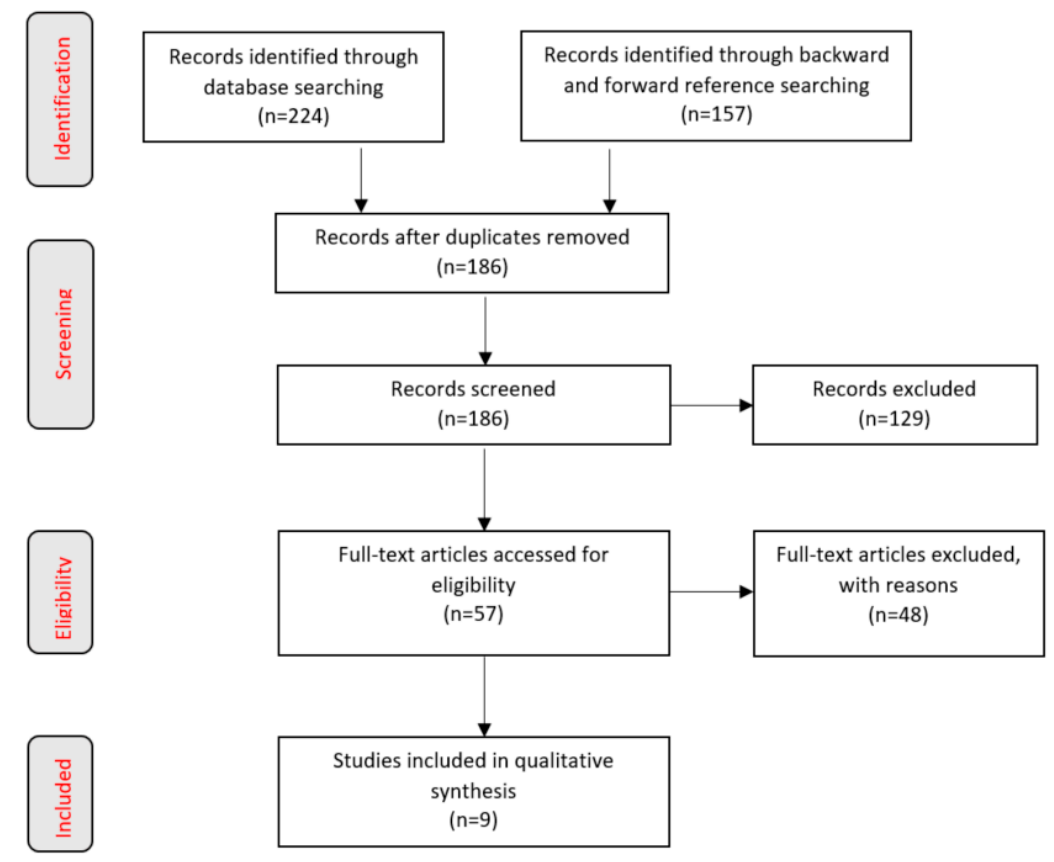

Figure 1. Flow chart of the research and selection process, following Moher, Liberati, Tetzlaff, and Altman, 2009 own presentation according to Walter et al. (2018) [19].

\section{Results: Models of Intersectoral Cooperation}

For the content analysis of the publications, those approaches were described as 'models' that address the process of intersectoral cooperation as a whole, taking into account phases and/or a complex structure of actors. Accordingly, a model offers a reduced picture of intersectoral cooperation as such. The term 'instruments' was used to describe those representations in which the design of selected processes as partial elements of intersectoral cooperation were in the foreground, for example monitoring, team cooperation, or leadership behavior [19]. Of the 57 full texts viewed, only nine publications refer directly to a model of intersectoral cooperation in the defined sense and present it in detail.

All nine publications included in the full-text analysis describe the respective models as an overall process of intersectoral cooperation in varying degrees of detail and with various focal points. While individual authors focus on the phase-related process from the establishment of a network for intersectoral cooperation to the evaluation of the intervention, other publications focus more on basic recommendations for action or guidelines that are identified as crucial for the success of the cooperation. Still others address other, selected issues with a special focus, which in the authors' view is also central to successful intersectoral cooperation. In a content-analytical procedure, three categories were identified according to which the nine models mentioned can be structured. Figure 2 gives an overview of the identified categories with a brief description of them. Table 2 contains a summary of the nine included sources on models of intersectoral cooperation. These are assigned to the three categories shown in Figure 2.

\begin{tabular}{|l|}
\hline $\begin{array}{l}\text { A) Detailed cyclical phase } \\
\text { models }(\mathbf{n}=\mathbf{3})\end{array}$ \\
\hline Models that represent \\
the process of \\
intersectoral cooperation \\
as a detailed sequence of \\
steps \\
\hline
\end{tabular}

\begin{tabular}{|l||l|}
\hline $\begin{array}{l}\text { B) Models with general } \\
\text { guidelines }(\mathbf{n}=\mathbf{3})\end{array}$ & \begin{tabular}{|l|} 
C) Models with a special \\
focus $(\mathbf{n}=\mathbf{3})$
\end{tabular} \\
\hline $\begin{array}{l}\text { - Models that formulate } \\
\text { general guidelines for } \\
\text { intersectoral cooperation } \\
\text { in addition to sequences }\end{array}$ & $\begin{array}{l}\text { - Models with a special } \\
\text { focus on selected } \\
\text { questions or topics of } \\
\text { intersectoral cooperation }\end{array}$ \\
\hline
\end{tabular}

Figure 2. Classification of the models for intersectoral cooperation. 
Table 2. Publications on models of intersectoral cooperation according to the three categories.

\begin{tabular}{|c|c|c|c|}
\hline & Author/Model & Subject & Quintessences \\
\hline \multirow{3}{*}{ 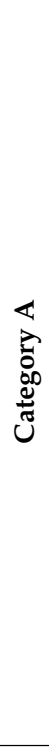 } & $\begin{array}{c}\text { Shapiro et al. (2015): } \\
\text { Communities That Care } \\
\text { [28] }\end{array}$ & $\begin{array}{l}\text { Strengthening the } \\
\text { coalition capacity and } \\
\text { science-based health } \\
\text { promotion of adolescents } \\
\text { in the community }\end{array}$ & $\begin{array}{l}\text { Core of the CTC }{ }^{\circledR} \text { Program: 5-phase } \\
\text { procedure from the founding of an alliance } \\
\text { to evaluation. The success components of } \\
\text { the CTC }{ }^{\circledR} \text { Program are the consistent, } \\
\text { science-based survey of the concrete, } \\
\text { specific needs and the orientation towards } \\
\text { evidence-based measures }\end{array}$ \\
\hline & $\begin{array}{l}\text { Landschaftsverband } \\
\text { Rheinland (2017): } \\
\text { Strategy cycle network } \\
\text { cooperation [29] }\end{array}$ & $\begin{array}{l}\text { Networks against child } \\
\text { poverty as an integrated } \\
\text { overall } \\
\text { strategy/prevention } \\
\text { chains in municipalities } \\
\text { in the Rhineland. }\end{array}$ & $\begin{array}{l}\text { 10-step strategy cycle including clarification } \\
\text { of mission and mission statement } \\
\text { development, network analysis and } \\
\text { steering group formation, involvement of } \\
\text { policymakers and the public, needs } \\
\text { assessment, implementation, monitoring } \\
\text { and evaluation to assess effectiveness }\end{array}$ \\
\hline & $\begin{array}{l}\text { Fawcett et al. (2010): } \\
\text { Institute of Medicine } \\
\text { Framework for } \\
\text { Collaborative Action [30] }\end{array}$ & $\begin{array}{l}\text { Successful interventions } \\
\text { in the public health } \\
\text { sector as a guideline } \\
\text { model for communities. }\end{array}$ & $\begin{array}{l}\text { 12-step model; elements: clear } \\
\text { responsibilities and action plans, resources: } \\
\text { training and technical support, creating } \\
\text { good cooperation conditions and } \\
\text { appropriate financing, participatory } \\
\text { evaluation systems, systematic } \\
\text { measurement of progress }\end{array}$ \\
\hline \multirow{3}{*}{ 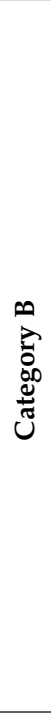 } & $\begin{array}{l}\text { Towe et al. (2016): } \\
\text { Health Action } \\
\text { Framework [31] }\end{array}$ & $\begin{array}{l}\text { Improving health and } \\
\text { well-being through the } \\
\text { Health Action } \\
\text { Framework. }\end{array}$ & $\begin{array}{l}\text { Three key requirements for collaborations: } \\
\text { (1) number, breadth and quality of } \\
\text { partnerships, (2) adequacy and reliability of } \\
\text { investment, (3) guidelines to promote } \\
\text { collaboration. }\end{array}$ \\
\hline & $\begin{array}{l}\text { Politis et al. (2017): } \\
\text { CLASP-Pathways to } \\
\text { policy [32] }\end{array}$ & $\begin{array}{l}\text { Strategic pathways in the } \\
\text { CLASP program for } \\
\text { physical activity and } \\
\text { built environment; } \\
\text { success factors for policy } \\
\text { changes. }\end{array}$ & $\begin{array}{l}\text { Building relationships and sharing } \\
\text { expertise and new or expanded staff } \\
\text { positions, creating and sharing approaches } \\
\text { and resources, enabling knowledge to be } \\
\text { gained on effectiveness, building genuine } \\
\text { willingness to cooperate and formalized } \\
\text { partnerships and cooperation structures. }\end{array}$ \\
\hline & $\begin{array}{l}\text { Shrimali et al. (2013): } \\
\text { Building Blocks } \\
\text { Collaborative [33] }\end{array}$ & $\begin{array}{l}\text { Strategic partnerships to } \\
\text { improve health equity in } \\
\text { low-income communities }\end{array}$ & $\begin{array}{l}\text { (1) Forging alliances and visions, (2) } \\
\text { Broadening perspectives on health } \\
\text { conditions, (3) Project development. } \\
\text { Success factors: strong leadership, } \\
\text { committed employees, ownership, flexible } \\
\text { partnership structure, support for capacity } \\
\text { building, promotion of learning, exchange } \\
\text { and development, project resources. }\end{array}$ \\
\hline \multirow{3}{*}{ 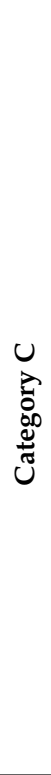 } & $\begin{array}{l}\text { De Montigny et al. } \\
\text { (2017): Fundaments of } \\
\text { cross-sector collaboration } \\
\text { for health promotion [34] }\end{array}$ & $\begin{array}{l}\text { Inter-sectoral } \\
\text { cooperation with a } \\
\text { special focus on } \\
\text { maintaining motivation, } \\
\text { willingness to learn and } \\
\text { sustainability }\end{array}$ & $\begin{array}{l}\text { Framework of sustainable cooperation: } \\
\text { common agenda, appreciation of different } \\
\text { perspectives (including those of the actors), } \\
\text { flexibility and positive effects for partner } \\
\text { organizations themselves, open, } \\
\text { transparent communication and constant } \\
\text { willingness to learn. }\end{array}$ \\
\hline & $\begin{array}{c}\text { Willis et al. (2016): } \\
\text { Learning and } \\
\text { improvement strategy } \\
{[35]}\end{array}$ & $\begin{array}{l}\text { Learning and } \\
\text { development strategy of } \\
\text { the Canadian initiative } \\
\text { for multisectoral } \\
\text { partnerships for the } \\
\text { prevention of chronic } \\
\text { diseases as an action } \\
\text { research project }\end{array}$ & $\begin{array}{l}\text { Understanding of administrative actions, } \\
\text { trust in cooperation and stable cooperation } \\
\text { structures, visualization of existing } \\
\text { resources and their creation, capacity } \\
\text { building and sufficient time perspectives } \\
\text { for successful networking. These elements } \\
\text { can be made useful as further training } \\
\text { modules for process partners. }\end{array}$ \\
\hline & $\begin{array}{l}\text { Johnston and Finegood } \\
\text { (2015): Model of } \\
\text { integrating cross-sector } \\
\text { Partnership [36] }\end{array}$ & $\begin{array}{l}\text { Partnerships between the } \\
\text { health sector and the } \\
\text { private sector to prevent } \\
\text { obesity and chronic } \\
\text { diseases. }\end{array}$ & $\begin{array}{l}\text { Challenges, risks and benefits of } \\
\text { cross-sector partnerships as integrated } \\
\text { forms of action and organization. Core } \\
\text { elements: trustful cooperation, active, } \\
\text { moderating handling of conflicts of interest, } \\
\text { consistently applied monitoring and } \\
\text { evaluation of interventions. }\end{array}$ \\
\hline
\end{tabular}


Category A models describe the process of intersectoral cooperation in central stages and, in some cases, the associated detailed steps. For example, the publication by Shapiro, Oesterle, and colleagues (2015) [28] outlines a model with the Communities-That-Care ${ }^{\circledR}$ Program $\left(\mathrm{CTC}^{\circledR}\right)$, which has gained recognition and attention in science and practice beyond the borders of the USA. Based on more than 30 years of practice, the five phases of the $\mathrm{CTC}^{\circledR}$ Program are thoroughly described in their facets and give a clear structure to intersectoral cooperation. The $\mathrm{CTC}^{\circledR}$ model pays particular attention to the preparatory phases: three of the five steps deal with the creation of a municipal alliance focused on specific challenges of growing up in the municipality. In the $C T C^{\circledR}$ Program, this alliance analyzes a locally identified problem situation intensively, draws up a municipal profile, and prepares for the joint work in further training courses. Grounded on the specified analysis of the actual local needs, interventions are planned in the fourth stage of the $\mathrm{CTC}^{\circledR}$ cycle, implemented in the fifth stage, and finally are monitored and evaluated in terms of results and findings [28]. The Rhineland Regional Council's strategy cycle network cooperation also focuses on improved conditions for growing up with a prevention network against child poverty. There is great care taken in the preparation of the interventions as well. Seven of ten implementation steps address preparatory measures with basic strategic steps. For example, the analysis of existing networks avoids the formation of duplicate structures, the development of a mission statement creates a high degree of commitment and is the basis for a local political decision. This puts the issue of child poverty on the political agenda and combines this with sensitizing publicity measures. The strategy cycle also emphasizes the importance of monitoring and evaluating the implemented measures [29]. The team of authors around Fawcett et al. (2010) [30] dedicates their Framework for Collaborative Action to general community-based health promotion. This model is developed based on the US Institute of Medicine, systematically taking into account scientific findings and practical experience. Similar to an organizational development process, the framework model for the initial phase of intersectoral cooperation places great emphasis on developing a vision and agreeing on a common purpose. The development of leadership qualities, the provision of technical infrastructure and the perpetuation of success are central to the continuation of the cooperation [30].

Category B models also deal with process-related sequences of steps in intersectoral cooperation, and at the same time they elaborate central principles of cooperation design. These principles are pronounced as generally binding guidelines for cross-sectoral cooperation in the corresponding publications. Even the subtitle in Vivian Towe and colleagues refers to "essential ingredients" for better health promotion and interprets intersectoral cooperation as the second field of action in the four-part framework for action of the Health Action Framework. The authors work out three central driving forces of successful cooperation. (1) The number, breadth and quality of partnerships: The central issue here is to find an adequate number of topic-relevant stakeholders for a coalition and to awake their willingness to get involved. The implementation of this is also a question of leadership quality and still is addressed only sparsely in literature and practice. (2) The factor of appropriateness of investment refers to the time needed for efforts to improve health to be effective. This goes with the need for a reliable and continuous supply of monetary and non-monetary resources. (3) As a third driving force, the importance of guidelines for the promotion of intersectoral cooperation at federal, state, and municipal level is identified. These include legal requirements but also administrative procedures for implementing intersectoral cooperation [31]. Politis et al. (2017) [32] formulate central findings from a Canadian initiative: The CLASP initiative for Pathways to Policy initiates coalitions of practice, policy, and research to exchange best practice examples and strategic pathways for more physical activity and urban development. The aim is to identify success factors for policy changes. The authors emphasize the importance of building relationships between stakeholders and the space needed to exchange different expertise. This goes hand in hand with the necessity to make the specific working approaches to each sector transparent and comprehensible. Resources are needed to be available to the partners in the process, but they also have to provide their own resources for the network and create new staff positions, or at the very least increase the number of positions for intersectoral cooperation. 
Furthermore, exchange and further training on questions of effectiveness are essential, as is the genesis of formalized structures and partnerships for cooperation [32]. As a Building Blocks Collaborative for improving the living conditions of children in low-income communities, Shrimali et al. (2014) [33] are dedicated to building strategic partnerships between numerous sectors such as economic development, food supply, administrations, clinics, housing, green space and leisure facilities, as well as advocacy groups for community regeneration. This publication also emphasizes the importance of leadership, employee engagement, fostering collaborative learning and providing project resources. Furthermore, the authors point out the benefits of a flexible partnership structure and personal responsibility in the partnering process [33].

Models in category $\mathrm{C}$ work out particular partial aspects of intersectoral cooperation. The special focus on learning processes and maintaining commitment as the basis for the sustainability of cooperation and its outcomes is taken up by the Foundations of Cross-Sector Collaboration for Health Promotion of the Canadian research team around de Montigny (2017) [34]. In their publication, the authors present basic theories of organizational psychology as well as learning theories, and link these with findings on international development cooperation. On that basis they form an essential framework for sustainable cooperation in the form of the elaboration of a common agenda, flexibility of cooperation and the visualization of positive effects for the partner organizations themselves. They also emphasize the relevance of open, transparent communication and the appreciation of different perspectives, explicitly including the views of the users [34]. The continuous improvement process in a research project on the prevention of chronic diseases as a Learning and Improvement Strategy is the focus of Willis et al. (2016) [35]. As a result of their action research, the authors present strategic keystones of a multi-professional partnership: solid cooperation structures, trust in the cooperation, transparency regarding existing resources and possibilities of exploitation. Insight into administrative processes and understanding of administrative action, an appropriate time perspective for networked activities and opportunities for capacity building are important as well. The authors suggest that these core elements of successful intersectoral cooperation should become templates as training modules for process partners and thus made usable [35]. Sustainability and openness also play a role in the Model of Integrating Cross-Sector Partnership after Johnston and Finegood (2015) [36], but under the special auspices of a coalition between the health sector and the private sector for the prevention of obesity and chronic diseases. The goal of an integrated form of action and organization between these players is characterized by the particular challenge of overcoming the different interests and assessments in each case. Key factors for this are cooperation based on trust, an active, moderating approach to conflicts of interest, consistently well thought-out and applied monitoring, and the systematic evaluation of interventions carried out [36].

The analysis of the publications thus illustrates the enormous heterogeneity of models of intersectoral cooperation. A detailed examination of the common features of the individual models shows that many models are oriented in their core to the schematic procedure of the Public Health Action Cycle $[37,38]$ and place great emphasis on preparatory analysis steps and elements of strategy development. Furthermore, the close interrelationships of intersectoral health promotion activities with the levels of politics and administration become clear. On this basis, they emphasize challenges, but also the undoubted necessity to work consciously and actively with these influencing factors. The analysis of the models also highlights the enormous importance of leadership and the special weight of good moderation in cooperation, on which the success of cooperation seems to depend to a large extent. It is also noticeable that several models emphasize the willingness and ability to learn. Based on this, an attempt will now be made to bring together the seemingly central commonalities of the nine models analyzed in the review into the first draft of a synthesis model. Figure 3 shows this synthesis, whereby the outer circle identifies the identified commonalities as central strategic steps of intersectoral cooperation, while the inner field of the scheme focuses on common insights for the design of internal cooperation. 


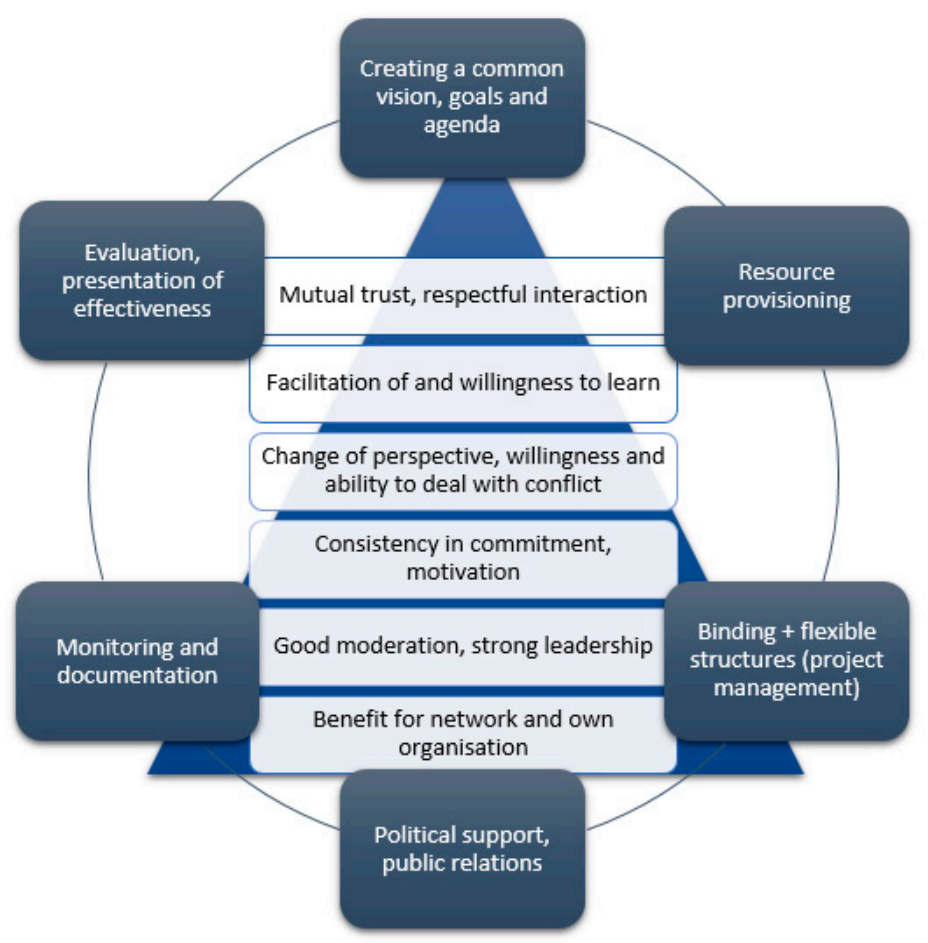

Figure 3. Central common features of the nine models of intersectoral cooperation as first draft of a synthesis model.

\section{Discussion}

The presented models show the wide range and variety of requirements for intersectoral cooperation. While the phase-related process of cooperation and networking with variance of some detailed steps essentially corresponds to the Public Health Action Cycle, the publications also focus on detailed questions as criteria for success. These are strongly determined by the respective starting positions and practical references of the individual publications: Depending on which concrete partnerships are involved in dealing with the respective health problem, the focus in the evaluation of success factors also shifts. The first draft of a synthesis model in Figure 3 therefore points to those factors that have played an important role for all models analyzed. It becomes clear that organizational development processes are necessary for sustainable cross-sectoral cooperation. These processes partly concern internal organizational development and just the same network-oriented cooperation as a whole. For the partnership-based and resilient networking of different departments, which for instance brings together the topics of health, social affairs, environment and urban planning in the sense of dealing with municipal future tasks, organization-internal mental models, official insular thinking and arrest in institutional routines that have grown over many years must be dealt with in the highest quality and overcome in favor of an orientation towards intersectoral partnership. The enormous challenge of making adequate resources and reliable activity perspectives available across sector boundaries is another formative but critical success factor. A decisive basis for the targeted acquisition of knowledge on good practice in intersectoral cooperation will be to promote a systematic and continuous exchange between institutions, practitioners, and academia [19]. This would give a chance to gain practical knowledge and reduce the gap between different approaches to intersectoral cooperation with scientific support. The aim could be to develop a jointly supported model as a basis for intersectoral cooperation, which can therefore function in the sense of the legally anchored framework directive called for by Towe et al. (2016) [31]. In this context, the synthesis model presented above could provide a first orientation towards a common framework model. Resources would have to be made available here to systematically test this model in the development and implementation of intersectoral cooperation networks and to analyze it with regard to difficulties and successes. The thematic focus 
on environmental justice in urban areas would provide a good common framework for this: here a comparability in the procedure and in the selection of the cooperation partners would be much better than was guaranteed in the review itself due to the large thematic spread. At the same time, it would be possible to discuss questions of evidence from the outset and to define specific criteria for their collection, so that the effectiveness of intersectoral cooperation in a selected thematic field can be better determined. Here, policy-makers are called upon to provide sufficient and appropriate resources for such a research program.

The results of the review should be additionally supplemented, expanded, and deepened by further systematic reviews. Transdisciplinary research designs could also accompany promising design features of intersectoral cooperation and test their effectiveness and theory content. This could be achieved more effectively if research activities were conducted in a coordinated manner under the umbrella of a coordination office for research and practice transfer for intersectoral cooperation and findings were consistently published [19]. If intersectoral cooperation is developed to become the hoped-for powerful instrument for overcoming social, health, and environmental inequality that is assigned to it in numerous strategy papers, all those strategies of accompanying and networked research and a systematic theory-research-practice transfer would be fundamental. In particular, however, questions of permanence and sustainability will presumably only be achievable and verifiable through concerted research and transfer work and innovative forms of practical support. Since, however, especially those questions of sustainability and perpetuation can only be answered in isolation from the respective individual goals of an individual research project, but can undoubtedly also be regarded as a common bracket and meta-goal of intersectoral cooperation, such overarching, long-term framework conditions and a concerted approach should be supported by policymakers and actors and backed up with appropriate resources.

Author Contributions: Conceptualization, E.Q., S.K. and U.W.; methodology, E.Q., S.K. and U.W.; investigation, E.Q., S.K. and U.W.; writing—original draft preparation, E.Q. and S.K.; writing—review and editing, M.K., J.L. and U.W.; visualization, S.K.; funding acquisition, E.Q. and U.W. All authors have read and agreed to the published version of the manuscript.

Funding: This research was funded by the Federal Centre for Health Education (BZgA). The BZgA is a specialist authority within the portfolio of the Federal Ministry of Health. The APC was funded by the University of Applied Sciences, Bochum (Hochschule für Gesundheit, Bochum).

Conflicts of Interest: The authors declare no conflict of interest. The authors declare that there are no personal circumstances or interest that can be perceived as inappropriately influencing the representation or interpretation of reported research results. The funder of the study has commissioned a scoping review and defined overarching research questions. Furthermore the funder had no role in the design of the study; in the collection, analyses, or interpretation of data; but the funder was informed about the design of the study. The funder had no influence in the writing of the manuscript, or in the decision to publish the results in the journal.

\section{References}

1. Lampert, T.; Hoebel, J.; Kroll, L.E. Soziale Unterschiede in Deutschland: Mortalität und Lebenserwartung. J. Health Monit. 2019, 4. [CrossRef]

2. World Health Organization. Review of Social Determinants and the Health Divide in the WHO European Region; World Health Organization: Geneva, Switzerland, 2013.

3. Marmot, M. The health gap: The challenge of an unequal world. Lancet 2015, 386, 2442-2444. [CrossRef]

4. Landrigan, P.J.; Fuller, R.; Acosta, N.J.R.; Adeyi, O.; Arnold, R.; Basu, N.; Baldé, A.B.; Bertollini, R.; Bose-O'Reilly, S.; Boufford, J.I. The Lancet Commission on pollution and health. Lancet 2018, 391, 462-512. [CrossRef]

5. Tobollik, M.; Kabel, C.; Hornberg, C.; Plaß, D. Übersicht zu Indikatoren im Kontext Umwelt und Gesundheit. Bundesgesundheitsblatt Gesundh. Gesundh. 2018, 61,710-719. [CrossRef]

6. Claßen, T.; Bunz, M. Einfluss von Naturräumen auf die Gesundheit-Evidenzlage und Konsequenzen für Wissenschaft und Praxis. Bundesgesundheitsblatt Gesundh. Gesundh. 2018, 61, 720-728. [CrossRef]

7. Robert-Koch-Institut. Gesundheit in Deutschland; Gesundheitsberichterstattung des Bundes. Gemeinsam Getragen von RKI und Destatis; Robert-Koch-Institut: Berlin, Germany, 2015. 
8. Robert-Koch-Institut. KiGGS Welle 2-Erste Ergebnisse aus Querschnitt-und Kohortenanalysen. J. Health Monit. 2018, 3. [CrossRef]

9. Kupfer, A.; Gamper, M. Migration als gesundheitliche Ungleichheitsdimension? Natio-ethno-kulturelle Zugehörigkeit, Gesundheit und soziale Netzwerke. Soz. Netzw. Gesundh. Ungleichheiten 2020, 369-397. [CrossRef]

10. Gewerkschaftsbund, D. Gesundheitsrisiko Arbeitslosigkeit-Wissensstand, Praxis und Anforderungen an eine Arbeitsmarktintegrative Gesund-Heitsförderung. 2010. Available online: http:// www.forschungsnetzwerk.at/downloadpub/2010_dgb_Gesundheitsrisiko_arbeitslosigkeit.pdf (accessed on 12 August 2020).

11. Krug, G.; Brandt, S.; Gamper, M.; Knabe, A.; Klärner, A. Arbeitslosigkeit, soziale Netzwerke und gesundheitliche Ungleichheiten. Soz. Netzw. und gesundheitliche Ungleichheiten. 2020, 309-328. [CrossRef]

12. Kastl, J.M. Einführung in die Soziologie der Behinderung., 2nd ed.; Verlag für Sozialwissenschaften: Wiesbaden, Germany, 2016.

13. Brandhorst, A. Kooperation und Integration als Zielstellung der gesundheitspolitischen Gesetzgebung. Koop. Integr. Unvollendete Proj. Gesundh. 2017, 13-30. [CrossRef]

14. Dahlgren, G.; Whitehead, M. Levelling up (Part 2): A Discussion Paper on European Strategies for Tackling Social Inequities in Health. 2006. Available online: https:/apps.who.int/iris/bitstream/handle/10665/107791/ E89384.pdf? sequence=1\&isAllowed=y (accessed on 12 August 2020).

15. World Health Organization. Targets and Beyond-Reaching New Frontiers in Evidence. The European Health Report. 2015. Available online: https://www.euro.who.int/en/publications/abstracts/european-health-report2015-the--targets-and-beyond-reaching-new-frontiers-in-evidence.-highlights (accessed on 12 August 2020).

16. Böhme, C.; Stender, K.-P. Gesundheitsförderung und Gesunde/Soziale Stadt/Kommunalpolitische Perspektive. 2015. Available online: http://www.bzga.de/leitbegriffe (accessed on 12 August 2020).

17. Köckler, H. Sozialraum und Gesundheit. Gesundheitswissenschaften. 2019, pp. 517-525. Available online: https://link.springer.com/chapter/10.1007/978-3-662-58314-2_48 (accessed on 12 August 2020).

18. Böhme, C.; Bunge, C.; Preuß, T. Umweltgerechtigkeit in der Stadt-Zur integrierten Betrachtung von Umwelt, Gesundheit, Sozialem und Stadtentwicklung in der kommunalen. Umweltpsychologie 2016, 20, 137-157.

19. Walter, U.; Röding, D.; Kruse, S.; Quilling, E. Modelle und Evidenzen der Intersektoralen Kooperation in der Lebensweltbezogenen Prävention und Gesundheitsförderung. 2018. Available online: https://www.gkvbuendnis.de/fileadmin/user_upload/Publikationen/Bericht_Intersektorale-Kooperation_2019.pdf (accessed on 12 August 2020).

20. Praxisdatenbank Gesundheitliche Chancengleichheit. 2019. Available online: https://www.gesundheitlichechancengleichheit.de/praxisdatenbank/ueber-die-praxisdatenbank/ (accessed on 12 August 2020).

21. Soziale Lage und Gesundheit: Ursachen. Available online: https://www.gesundheitliche-chancengleichheit. de/kooperationsverbund/hintergruende-daten-materialien/ (accessed on 12 August 2020).

22. Brown, E.C.; Hawkins, D.; Rhew, I.C.; Shapiro, V.B.; Abbott, R.D.; Oesterle, S.; Arthur, M.W.; Briney, J.S.; Catalano, R. Prevention system mediation of Communities That Care effects on youth outcomes. Prev. Sci. 2014, 15, 623-632. [CrossRef] [PubMed]

23. Downey, L.H.; Thomas, W.A.; Gaddam, R.; Scutchfield, F.D. The relationship between local public health agency characteristics and performance of partnership-related essential public health services. Health Promot. Pract. 2013, 14, 284-292. [CrossRef] [PubMed]

24. Steenbakkers, M.; Jansen, M.; Maarse, H.; de Vries, N. Challenging Health in All Policies, an action research study in Dutch municipalities. Health Policy 2012, 105, 288-295. [CrossRef] [PubMed]

25. Frantz, I.; Heinrichs, N. Populationseffekte Einer Flächendeckenden Implementierung Familienbasierter Präventionsprogramme. 2016. Available online: https:/econtent.hogrefe.com/doi/full/10.1026/1616-3443/ a000344 (accessed on 12 August 2020).

26. Quilling, E.; Kruse, S. Evidenzlage Kommunaler Strategien der Prävention und Gesundheitsförderung: Eine Literatur- und Datenbankrecherche (Rapid Review). 2018. Available online: https: //www.researchgate.net/publication/341670274_Evidenzlage_kommunaler_Strategien_der_Praven_ on_und_Gesundheitsforderung_Eine_Literatur-_und_Datenbankrecherche_Rapid_Review (accessed on 12 August 2020).

27. Chircop, A.; Bassett, R.; Taylor, E. Evidence on how to practice intersectoral collaboration for health equity: A scoping review. Crit. Public Health 2015, 25, 178-191. [CrossRef] 
28. Shapiro, V.B.; Oesterle, S.; Hawkins, J.D. Relating coalition capacity to the adoption of science-based prevention in communities: Evidence from a randomized trial of Communities That Care. Am. J. Community Psychol. 2015, 55, 1-12. [CrossRef]

29. Landschaftsverband Rheinland, K.K.i.L.-L. Präventionsnetzwerke und Präventionsketten erfolgreich koordinieren. Eine Arbeitshilfe aus dem LVR-Programm. 2017. Available online: https://www.lvr.de/de/nav_ main/jugend_2/jugendmter/koordinationsstellekinderarmut/koordinationsstellekinderarmut_1.jsp (accessed on 12 August 2020).

30. Fawcett, S.; Schultz, J.; Watson-Thompson, J.; Fox, M.; Bremby, R. Peer Reviewed: Building Multisectoral Partnerships for Population Health and Health Equity. 2010; Volume 7. Available online: https://www.ncbi. nlm.nih.gov/pmc/articles/PMC2995607/ (accessed on 12 August 2020).

31. Towe, V.L.; Leviton, L.; Chandra, A.; Sloan, J.C.; Tait, M.; Orleans, T. Cross-sector collaborations and partnerships: Essential ingredients to help shape health and well-being. Health Aff. 2016, 35, 1964-1969. [CrossRef]

32. Politis, C.E.; Mowat, D.L.; Keen, D. Pathways to policy: Lessons learned in multisectoral collaboration for physical activity and built environment policy development from the Coalitions Linking Action and Science for Prevention (CLASP) initiative. Can. J. Public Health 2017, 108, 192-198. [CrossRef]

33. Shrimali, B.P.; Luginbuhl, J.; Malin, C.; Flournoy, R.; Siegel, A. The building blocks collaborative: Advancing a life course approach to health equity through multi-sector collaboration. Matern. Child Health J. 2014, 18, 373-379. [CrossRef]

34. De Montigny, J.G.; Desjardins, S.; Bouchard, L. The fundamentals of cross-sector collaboration for social change to promote population health. Glob. Health Promot. 2019, 26, 41-50. [CrossRef]

35. Willis, C.D.; Greene, J.K.; Abramowicz, A.; Riley, B.L. Strengthening the evidence and action on multi-sectoral partnerships in public health: An action research initiative. Health Promotion and Chronic Disease Prevention in Canada: Research. Policy Pract. 2016, 36, 101.

36. Johnston, L.M.; Finegood, D. Cross-sector partnerships and public health: Challenges and opportunities for addressing obesity and noncommunicable diseases through engagement with the private sector. Annu. Rev. Public Health 2015, 36, 255-271. [CrossRef] [PubMed]

37. Rosenbrock, R. Public health as a social innovation. Gesundh. Bundesverb Arzte Ofentl. Gesundh. (Ger.) 1995, $57,140$.

38. Rosenbrock, R.; Gerlinger, T. Gesundheitspolitik: Eine Systematische Einführung; Verlag Hans Huber: Bern, Switzerland, 2014.

(C) 2020 by the authors. Licensee MDPI, Basel, Switzerland. This article is an open access article distributed under the terms and conditions of the Creative Commons Attribution (CC BY) license (http://creativecommons.org/licenses/by/4.0/). 